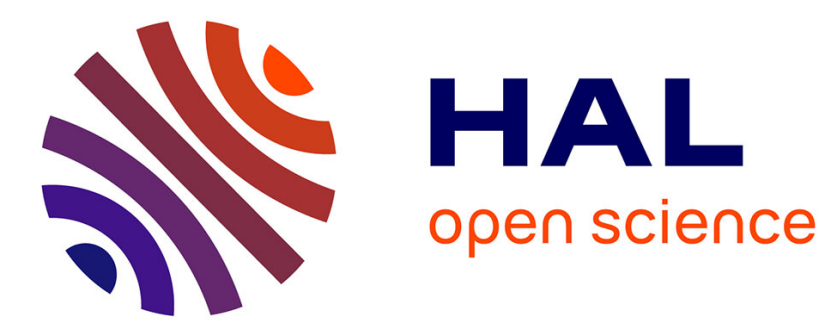

\title{
"Free to do what I want"? Exploring the ambivalent effects of liberating leadership
}

Hélène Picard, Gazi Islam

\section{To cite this version:}

Hélène Picard, Gazi Islam. "Free to do what I want"? Exploring the ambivalent effects of liberating leadership. Organization Studies, In press. halshs-01958935

\section{HAL Id: halshs-01958935 https://shs.hal.science/halshs-01958935}

Submitted on 18 Dec 2018

HAL is a multi-disciplinary open access archive for the deposit and dissemination of scientific research documents, whether they are published or not. The documents may come from teaching and research institutions in France or abroad, or from public or private research centers.
L'archive ouverte pluridisciplinaire HAL, est destinée au dépôt et à la diffusion de documents scientifiques de niveau recherche, publiés ou non, émanant des établissements d'enseignement et de recherche français ou étrangers, des laboratoires publics ou privés. 
running head: AMBIVALENT EFFECTS OF LIBERATING LEADERSHIP

"Free to do what I want"? Exploring the ambivalent effects of liberating leadership.

Picard, H. \& Islam, G. (in press) "Free to do what I want"? Exploring the ambivalent effects of liberating leadership. Organization Studies

\begin{abstract}
The current study examines the phenomenon of "liberating leadership", an emerging trend promising self-mastery and collective unity, resonating with the literature on post-heroic leadership. We evaluate the claims of liberating leadership from a psychodynamic perspective, using a Lacanian approach. We examine how post-heroic forms of leadership reconfigures the symbolic and imaginary aspects of follower identification, with ambivalent effects. Drawing empirically on a case study of a Belgian banking department, we trace how a "liberating" leader was able to garner intense psychological attachment among followers, accompanied by the "dark sides" of personal exhaustion and breakdown, normative pressure to be overly happy, and the scapegoating of contrarian managers who represented symbolic prohibition. We discuss the implications of our study for psychodynamic approaches to leadership, and more generally, for critical research on the recent trends toward the humanistic, post-heroic turn in leadership practices.
\end{abstract}

\title{
Keywords
}

leadership, liberated companies, symbolic authority, superego, imaginary, jouissance, Lacan. 
In 2010, Alexandre Gérard, head of Chronoflex, initiated the transformation of his 300person company by suppressing bureaucratic rules, setting up self-managed teams and famously leaving on a world tour with his family in 2012 (Fauroux et al., 2015). For Bob Davids, founder of Smoke Cellars, employee empowerment involved regularly distancing himself, with no instructions other than "I'm gone for eight months...If you feel that it's critical to contact me...I want you to get up, solve the problem, and then send me an e-mail with the solution" (Getz, 2009, p.43). Similarly Harry Quadracci, of Quad Graphics, touted "Management by Walking Away" from day-to-day decision-making (Getz, 2009, p.36).

Chronoflex, Smoke Cellars and Quad Graphics are known as "liberated companies", as coined by Getz (2009) to describe a self-driven workforce, whose aim is "happiness at work" (Meissonier, 2014). Proponents of the "liberated" model promote "radical" shifts in leadership, imagining effective leaders as distant, even absent, in the workplace. In focusing on de-centering leadership from the figure of the leader, "liberating leadership" 1 echoes concepts of post-heroic leadership that are increasingly central to scholarly debates (Collinson, 2018; Eslen-Ziya \& Erhart, 2015). Even as post-heroic conceptions - looking beyond unitary notions of the leader (Pearce, Conger \& Locke, 2008) - become pivotal to leadership debates, critical voices have begun to question the emancipatory potentials of such approaches (Costas \& Taheri, 2012).

Equating the suppression of authority figures with workers' liberation is at best simplistic, and deserves critical examination, especially in light of recent work that problematizes democratizing and flattening organizational hierarchy (Jaumier, 2017; Sutherland, Land \& Böhm, 2014). Affirming the liberating effects of leader absence may ideologically occlude workplace problems (increased stress, degradation of collective bounds; e.g. Baldry et al., 2007). Yet we know

${ }^{1}$ We use liberating leadership without quotation marks throughout, unless referring to third party usage. This term is to be taken as the label used for the concept by Getz, and not as an adjective referring to an aspect of leadership in our own analysis. 
little about the individual and collective mechanisms triggered by the suppression of authority figures, a theme largely absent from current accounts of liberating leadership (Getz, 2009, 2011; Getz \& Carney, 2009) and by observers of ongoing experiments (Landivar \& Trouvé, 2017; Arnaud, Mills \& Legrand, 2016; Demailly, 2011).

Conceptually, the "absence-as-emancipating" theme resonates with recent psychoanalytic perspectives on the darker sides of "post-heroic" leadership (Costas \& Taheri, 2012; De Cock \& Böhm, 2007; Ford \& Harding, 2011). From a Lacanian perspective, weakening leader positions may problematically compromise symbolic authority (Costas \& Taheri, 2012; Vidaillet \& Gamot, 2015). Examining liberated companies' focus on absent leadership raises questions of how employees experience and respond to undermined symbolic authority in the context of post-heroic leadership. To address this research question, we draw upon a two-year, in-depth case study of a liberating leadership experience conducted in a banking unit in Belgium.

Our research contributes to emerging conversations between critical leadership approaches and psychoanalysis in two ways. First, we address the ambivalent aspects of liberating leadership for workers, in terms of the simultaneous experience of enjoyment and increase of interpersonal tension resulting from undermining symbolic authority. Recognizing this ambivalence helps interpret observed counter-intuitive reactions by followers, among whom claims of self-mastery and alienating experiences co-exist. Theorizing these reactions as symptomatic of weakened symbolic authority, we explain the role of the imaginary and enjoyment ${ }^{2}$ as central psychodynamic processes characterizing liberating leadership. Second, more broadly, this demonstration allows us to challenge dominant assumptions of post-heroic leadership discourses according to which suppressing

\footnotetext{
${ }^{2}$ We draw on Lacan's concept of "jouissance" as enjoyment beyond the (socially sanctioned) pleasure principle (Lacan, 1998): subjects involved in jouissance, involving the imperatives to "Enjoy!", refuse the symbolic, socially acceptable, law. The unattainability of full jouissance evokes the feeling that something extra is needed to overcome subjects' existential lack.
} 
leadership safeguards employee autonomy. Specifically, it allows us to refine the ambiguous nature of post-heroic leadership, which has been overlooked in current treatments of liberating leadership.

Our argument unfolds as follows: first, based on a brief literature review, we articulate a psychoanalytic interpretation of post-heroic leadership, focusing on symbolic authority and drawing implications for leader-follower engagement. Next, describing our case study methods and analytical strategy, we explore how liberating leadership shapes ambivalent experiences, unveiling the intensification of violence and alienation dynamics. We then discuss the implications for leadership that acknowledges symbolic authority while respecting desiring and divided subjectivities.

\section{From Heroic to Post-Heroic Leadership}

Critiques of "great man" theories of leadership (Beyer, 1999; Meindl, Erlich \& Dukerich, 1985) have problematized "romantic" notions of leadership, noting the mythical status of leaders as dominant ideological symbols. According to such critiques, the propagation of dominant leadership myths may obscure power dynamics at play in the day-to-day of typically asymmetrical and alienating (Gemmill \& Oakley, 1992) leader-followers relations.

In parallel, concerned with the limits of leader-centric approaches, alternative perspectives have promoted "post-heroic" leadership approaches (cf. Raelin, 2016), both those concerned with collective or plural forms of leadership and drawing from practice perspectives (Denis, Langley \& Sergi, 2012) and those coming from a critical leadership studies perspective (Collinson, 2018; Grint, 2010; Fletcher, 2004). While the former tend to de-center the leader and move from "unitary command" to shared leadership (Pearce, Conger \& Locke, 2008), the latter tend to explore the political possibilities of de-centering the figure of the leader (e.g. Eslen-Ziya \& Erhart, 2015; Sutherland et al., 2014).

Both of these approaches fall under the umbrella of "post-heroic" leadership (Collinson, 2018); however, the critical leadership approach emphasizes that the relational aspect can highlight 
the power and control dynamics within leadership processes. Thusly, Costas \& Taheri (2012) problematize the emancipatory possibilities of post-heroic leadership, and question calls for the facile abandoning of authoritarian leadership in favour of "authentic" variants. In short, the transition from heroic to post-heroic leadership perspectives raises new concerns about the critical possibilities of the latter.

In this context, the emerging phenomenon of liberating leadership (Getz, 2009) is of interest as an emblematic variant of post-heroic approaches. The liberating leadership concept emerged from applied management literature with calls to completely transform organizations (Getz, 2009; 2011). Liberating leadership "gurus" (Getz \& Carney, 2009) claim to transcend traditional leadership styles with a distinctive set of humanistic and egalitarian practices. Drawing upon a mix of leadership theories as well as positive psychology, liberating leadership also draws on empirical cases such as Gore, Oticon, FAVI, Semco, Harley Davidson, Smoke Cellars, Chronoflex and Quad Graphics, seen as innovative, "plural" (Salovaara \& Bathurst, 2016, p.2) and "radical" (Getz, 2009, p.34) organizations. More recently, a small, emerging literature has examined the theoretical, historical roots and practical implications of liberated companies and leadership, primarily in the francophone literature (Arnaud et al., 2016; Demailly, 2011; the special issue edited by Landivar \& Trouvé, 2017). Born from applied literature but drawing transversally across management and psychology research, liberating leadership is an embryonic and hybrid leadership approach that makes large claims about its transformative potential.

This potential derives from three central features, according to Getz (2009). First, liberating leaders cultivate an environment "that satisfies people's need for self-motivation", suppressing timeclocks, formal procedures and control protocols, but also suppressing middle management posts in an initial, radical gesture (as happened in Semco; Semler, 1993; and FAVI: Gilbert, Raulet-Crozet \& Teglborg, 2014). Turning away from the leader's person, the escape from formality is claimed to offer unprecedented possibilities for "self-growth". 
Second, leader-follower relations must evolve towards "intrinsic equality” (Getz, 2009, p.3739). Through empathy and tolerance for paradox, liberating leaders are to mix "soft and hard" practices (Getz, 2009, p.48), remaining open while maintaining the disposition to use disciplinary action when required. Third, liberating leaders must maintain a culture of self-direction and selfmanagement, stimulating employees to "emotionally own the vision" (Getz, 2009, p.41). While success criteria are defined by the leader (Holtz, 2017), employees are incited to identify with the narrative of liberation (Arnaud et al, 2016).

Based on these three criteria, liberating leaders seem to adopt a paradoxical posture. While distancing themselves to foster self-dependency (e.g. Zobrist at FAVI, cited in Getz \& Carney, 2009; Getz, 2009), they may still intervene to punish "wrongdoers" at any given moment (Getz, 2009, p.46). For instance, Ricardo Semler, as new CEO of Semco, fired sixty percent of the company's top managers, before championing entrepreneurial initiatives by employees across the organization (Semler, 1993).

In short, liberating leadership is emblematic of contemporary attempts to re-enchant leadership via so-called post-heroic approaches. The paradox of such approaches, juxtaposing empowerment with punishment, creates a tension that begs the question of how such styles are received in the workplace, which is the question to which we turn.

\section{Psychodynamics of Post-Heroic Leadership}

To the extent that liberating leadership appears in academic and popular management writings (Getz, 2009, 2011; Getz \& Carney, 2009; Salovaara \& Bathurst, 2016; Verhezen, 2010) as a panacea for $21^{\text {st }}$ century leadership, critical evaluation is needed to avoid the risk of creating new myths. As Grint (2010, p.103) warns, the "Romance of Leadership" noted by Meindl et al. (1985) may be replaced by a "Romance of (Post-Heroic) Collaborative Leadership" (Leonard, 2007). Echoing this concern, Ford and Harding (2011) note how fantasies of authentic self-expression are woven into 
contemporary leadership, while Collinson (2012) warns of "Prozac leadership", or excessively positive leadership styles that can draw resistance from followers, while nourishing organizational fantasies of invincibility. With the advent of these "new spirits" of leadership, we consider liberating leadership as an empirical phenomenon with increasing currency among corporate leaders. We propose to contribute to the much-needed critical evaluation of the "radical" promises of post-heroic and, specifically, liberating leadership, to illuminate the "discrepancies and controversies" (Salovaara \& Bathurst, 2016, p.3) in the experiences of leaders and followers. For this, we draw on a long-established (Gabriel \& Carr, 2002; Islam, 2014) literature on the psychodynamics of leadership, a useful framework for understanding the "dark sides" of leadership (Ford \& Harding, 2011; Petriglieri \& Stein, 2012; Vince \& Mazen, 2014).

Specifically, we integrate the critical resources of leadership analyses drawing on Lacanian concepts (Costas \& Taheri, 2012; Ford \& Harding, 2011; Schedlitzki, Edwards \& Kempster, 2017) which have highlighted issues of subjectivity, identification and authority that enable theorizing of the dark sides and, perhaps, even the inhumanity (Johnsen \& Gudmand-Høyer, 2010) of leaderfollower relations. A Lacanian perspective may provide a corrective to the positive bent of "postheroic" approaches (Avolio, Walubwa \& Weber, 2009), where promises of being instrumental to the liberation and happiness of followers may obfuscate dimensions of power, domination, violence or suffering arising from the practice of leadership (Vince \& Mazen, 2014). What is more, Lacanian concepts are particularly well-suited for post-heroic leadership because the concept of lack (Arnaud \& Vidaillet, 2018) helps think through the implications of the absent leader, the effects of such absence on the robustness of the symbolic order, and the consequences for followers. In this context, we ask whether, by eroding the symbolic order of the organization, post-heroic leadership opens up emancipatory spaces for leaders and followers or, conversely, promotes a resurgence of illusions of liberation and self-mastery that are emblematic of a compromised symbolic order (Roberts, 2005; Vidaillet \& Gamot, 2015). 


\section{The "Divided" Subject and the Politics of Identification}

From a Lacanian perspective, human experience is split between the ego and the unconscious subject. While the former asserts an autonomous, coherent self, the latter escapes conceptualization, and is marked by existential lack, a lack-of-being. This "divided subject" can never secure a "true identity", an integrated sense of self, yet continues to desire integration while identifying with external resources, characteristics available in the social world (Vanheule, Lievrouw \& Verhaeghe, 2003). Such resources are found in the "imaginary" and "symbolic" domains, which constitute the main sources for subjects' identification processes (Stavrakakis, 2008).

The imaginary registers the ego's identification to its images, in a narcissistic "jubilation and playful self-discovery" (Lacan, 2006, p.75-82); it encapsulates the experience of being "one", and activates our system of perception, self-consciousness, and understanding of ourselves as agents. During one's lifetime, one's ego is (re)formed in relation to the images or objects perceived as capturing a sense of a stable "self" (e.g. consumer goods, social prestige, the gaze of others). Yet the "discovery" of the self is also alienating, catching the subject in its (impossible) attempt to fix its nature into imaginary identifications, and creating a dependency on the gaze of others (Roberts, 2005, p.632). The reflection is thus also a trap. The sense of unity in self-identity remains momentary and elusive.

Subjects attempt to overcome the persistent lack of fleeting identifications, to reach a state of purported wholeness. This attempt drives them to enter the social order that pre-exists them (known as the symbolic order), identifying with powerful symbols (Kenny, 2012, p.1176) such as name, affiliation or social role. Participating in the symbolic order (Chaumon, 2004) permits subjects to accept symbolic authority, although a residual lack continues to exist. Because this lack is related to desire (Žižek, 1989, p.136-139), the social subject can emerge as a desiring subject through engagement with the collective, while continuing to be haunted by the possibility of incompleteness. 
The implications of such a "politics of identification" (Stavrakakis, 2008, p.1041) involve the enrolment of affective dimensions (desire, lack, love, recognition) as forces in power and control dynamics within organizations. But, specifically, how do the dynamics of identification affect the politics of post-heroic leadership?

\section{Leadership Identity, Absence and Lack}

Lacanian leadership studies largely focus on identification, stressing the inherent lack in leader identification and reflecting how subjects find emancipatory resources in such identifications (Driver, 2013). Recent studies take the followers' perspective (Ford \& Harding, 2015; Schedlitzki et al., 2017) to highlight how this impossible desire paradoxically sustains affective attachments between leaders and followers, a taboo but powerful relationship.

As noted above, the importance of the symbolic order in coping with subjective lack makes leadership an intensely affect-laden psychodynamic process. Studies focusing on post-heroic discourses of "authentic leadership" and "seemingly non-paternalistic" leadership (Costas \& Taheri, 2012, p.1199) note how subjects may seek autonomy and self-determination by distancing themselves from the grip of symbolic identifications. "Self-effacing" leaders, by opening dialogue and acknowledging lack, allow employees to distance themselves from the imposed master signifiers of the organization (Costas \& Taheri, 2012, p.1204-1205). However, while symbolic authority defines prohibitions (Lacan, 2006, p.230), it is also instrumental in maintaining a desiring subjectivity (Verhaeghe, 2000). If the leader withdraws from her function of incarnating an "imaginary representative" for symbolic authority (Arnaud, 2002, p.700), this function is endangered. By offering to obliterate any authority figure, post-heroic leadership might foreclose the potential for a more open symbolic order of the organization, the consequences of which could be a reinforcement of imaginary dynamics (Costas \& Taheri, 2012, p.1205-1208; Vidaillet \& Gamot, 2015, p.1000-1003). 
From this perspective, avoiding symbolic authority through self-effacing leadership can give rise to a persecuting superego among followers (Costas \& Taheri, 2012) or employees (Vidaillet \& Gamot, 2015). The superego is the "imperative of jouissance", an intimate and persistent injunction to "Enjoy!" (Salecl, 1994). Thus, "the subject is now subjected in his entirety to the law of the superego - the imperative of enjoyment - which he can never satisfy...this results in a permanent feeling of guilt that "he doesn't manage" (to be happy, fulfilled, strong, etc.) and exhaustion from the constant attempts to meet the demand" (Vidaillet \& Gamot, 2015, p.994). Even as these attempts to "manage" (irremediably) fail, subjects still retain a "residue", a bit of satisfaction in dissatisfaction, which sustains the desire for enjoyment (Müller, 2012; Stavrakakis, 2007, p.71-82) and drives continued effort (Kosmala \& Herrbach, 2006).

Contemporary organizations, in their tendency to eschew authority, have been characterized as focusing on enjoyment in Google-like "cultures of fun" (Fleming, 2009). Böhm and Batta similarly highlight the "management of enjoyment" where organizations re-create enjoyment "on a constant basis, [which] now becomes a political and economic factor" (2010, p.355).

In short, diminished symbolic authority and the demand to "enjoy" involve deep workplace changes, yet we know little about how workers experience the simultaneous "liberation" and new demands of absent leaders. Our case study traces the emergence of "liberating leadership" in a financial institution to examine how changes in symbolic and imaginary aspects of leadership/followership shape workers' personal and collective experiences.

\section{Case Study}

This research draws on a single case study of leader/followers dynamics within the banking department $\mathrm{BSI}^{3}$ located in Belgium, under the leadership of Paul (from 2006 to 2012). Paul referred

\footnotetext{
${ }^{3}$ All names of persons and organizations are pseudonyms.
} 
to himself as the "liberating leader", notably when articulating his experience in public talks (such as the 2011 conference we attended, titled "Liberating management in a banking unit") or when featured in a TV documentary (Meissonnier, 2014) as an exemplary "liberating leader". Paul also shared his "vision" publicly in his CV, his LinkedIn page, and in a professional magazine, explaining his career as guided by "a constant willingness to modernize management”.

BSI is a commercial banking department, composed of two commercial teams each of about ten people, a data analysis unit of eight people and an operational unit to manage payments and security issues. In 2006, Paul - a former consultant - was recruited as the new head of BSI, with the explicit mission of restructuring the department. As part of his function, Paul travelled weekly to a foreign subsidiary for a few months in 2007-2008. At the time, this imposed "part-time presence" led him to reflect on his very hands-on, controlling hold on his followers: "I had to abandon the illusion that I was in control of things". Paul's plan, in his words, became to "gradually withdraw from the day-to-day activities, up to the point that...I would basically be absent!".

The first author (henceforth referred to as "fieldworker") immediately recognised that the study of BSI presented a key opportunity for understanding the ambivalence of the increasingly popular "liberated companies". The fieldworker gained a particular interest in the figure of BSI's leader, who was (and remains) a vocal proponent of "liberating leadership", and who himself produced prolific written material contemporaneously with our study, thus allowing to observe how this powerful discourse unfolded in time (Vidaillet \& Gamot, 2015). Gaining access to the department during this ongoing leadership experiment offered an opportunity to enrich the picture through inclusion of followers' perspectives, an important dimension for the psychodynamics of leadership (Gabriel, 1997). Notably, the single case study format, typical of psychoanalytic frameworks combines methods of interviews, observation, and/or analysis of archival data (Kenny, 2012) to explore multiple layers of meaning (Arnaud, 2012). 


\section{Data Collection}

Our data set (see Table 1) comprises 47 in-depth interviews (taped and transcribed), archival data (emails, press articles, newsletters) and observations (briefing and team seminar), constituting a multiple-source database. The fieldworker gained access to the department in 2011 after meeting Paul at a public conference on "utopian management". Following this encounter, she contacted Paul to conduct an exploratory interview to confirm interest and to identify initial themes of inquiry regarding the most striking features of the changes implemented. The insistence on autonomy, trust, and transparency, along with the leader's withdrawal from the day-to-day work, were addressed in this interview. Paul agreed to welcome the fieldworker into BSI's office in Brussels, so that she could grasp in-depth the consequences of such changes on followers' work experience.

A first visit was organized at the end of 2011, of about eight working days, during which the fieldworker had the opportunity to converse informally and conduct 26 in-depth interviews, ranging between 1.5-2 hours. The interviews were open-ended, and loosely structured around key themes: Paul's role and the "new" practices implemented, perceptions of the group atmosphere, changes in day-to-day work and interpersonal relations. Interviews were carried out mainly with departmental members (middle- or top-level managers, sales representatives, administrative assistants, analysts) but also with higher-up officials and senior managers within the bank. After this visit, the fieldworker kept in contact with Paul and others on his team, exchanging emails and documents (PowerPoint presentations, internal newsletters, newspaper articles), which were also collected. The fieldworker was informed that Paul would be leaving BSI in late 2012, leading to a second weeklong visit to conduct shorter (about 45 minutes) follow-up interviews, during which the fallout of seven years under Paul's leadership was discussed (21 interviews).

\section{Analysis}


Working as a research team, we started our analysis by reading (and re-reading) carefully the texts collected, noting the emerging themes around leadership. The early steps of open coding (Strauss \& Corbin, 1990) took place during the data collection phases - reading the interviews at the end of the day, re-reading them upon returning from the field. From this first step, we explored tensions within meanings, which crystallized both around the controversial figure of Paul as "liberating leader", whose absence was both praised and contested, and around followers' experience of Paul's leadership. The effects most discussed involved the key dimensions of "autonomy" and "self-management", "recognition" and "visibility", "belongingness" and "values", "team" and "happy" atmosphere in the department.

Focusing on the ambivalent experience of followers in subjective and intersubjective terms, we saw links with the emerging literature on Lacanian studies of organizations (Arnaud, 2012; Contu et al., 2010), which addresses dynamics of identification, (abolition of) authority, and enjoyment in capitalist organizations. Our interpretative work was itself informed by (Lacanian) psychoanalytical ideas (Parker, 2005). Thus, we moved between earlier codes and a re-reading of the texts themselves - focusing particularly on interview transcripts and instances of communication between leader and followers - to refine our theoretical constructs. Key to such interpretation is acknowledging that any account of the lived experience (conscious and unconscious) of being a follower is marked by lack (Schedlitzki et al., 2017), which implies that the analyst should attend to the "signifying elements that do not make sense" (Parker, 2005,p.168) in a text, within and across texts rather than looking to provide the unified, unproblematic truth of a phenomenon.

On an initial level, we noted ambivalence in the expression of Paul's perceived absence yet persistent influence in the work environment, which became a focus of our analysis. We examined how Paul's withdrawal enacted the "presence of this absence" in the symbolic order of the organization. At a second level, we explored followers' experience of "autonomy", leading us to examine imaginary processes of identification. At a third level, we examined the puzzling 
juxtaposition of exalting "teamwork" and expressing violence and aggression, interpreted as opposing manifestations of enjoyment within the collective of followers. Below, we present the case narrative according to these three analytical levels, as summarized in Table 2.

--------- Insert Table 2 about here --------

\section{Weakening the symbolic order through leader's absence}

Shaping the Followers' Group

Paul began with brutal staff cuts and authoritative "reorganizing", this taking place over a period of a few months and corresponding to the phase of "creat[ing] the environment" for liberation described by proponents of "liberating leadership" (Getz, 2009,p.37; Semler,1993). The newlyappointed leader fired about $30 \%$ of the department, mostly targeting middle managers and older employees, who retired or were transferred to other departments; younger staff, interns and managers selected by Paul replaced them.

Among the long-term employees and managers, the respondents remember these cuts as a painful moment, speaking of "war time" (Dorine), of their "brutality" (Alison) and their "painful" character (Michel). Striking is the sanguine attitude taken by Paul to the lay-offs:

"I was being asked to reorganize all this department which was completely, well it was the Court of Miracles! [...] it was a department that had never been valued within the bank...it was basically where they sent the old nags [...] Plus, I believe that when one has to really reorganize something, one must move really really fast in the beginning... that it enables one to really 'clean-up'. I don't want you to think I'm some kind of detergent [laughs], but to clean-up the filth." (Paul)

We note, first, that Paul repeats (three times in this short excerpt) the imperative to "reorganize", legitimated as the prerogative of top authorities to reach the organizationally sanctioned performance goals. Hierarchical position symbolically legitimates Paul's punitive power of exclusion through "reorganization".

Second, however, abundant metaphors evoke his perception of a dysfunctional department "the Court of Miracles", "old nags", "ruins" - but also a dirty, negligent collective - "clean-up", 
"detergent", "filth". These metaphors point to the lay-offs as a ritual act of purification of a pathological or corrupted collective body. This is reinforced by his repetition of the "clean-up" image, this also arising in interviews with followers (Alison, Michel, Claude). The imaginary contrast between then and now (a dynamic, valued, visible department) is stressed. The interviews, five years post-change, show the tension between the symbolic legitimacy of the lay-offs and their imaginary value, as an act of foundation of a new collective.

In short, Paul initially used his organizationally assigned (symbolic) position of authority to re-establish the collective of (soon to be) self-governed followers. The exclusion of those deemed unfit indicates the violence at the heart of this process, including at the level of language, with the use of brutal metaphors evoking a (fantasmatic) sense of wholeness that required purging "the filth".

\section{A Different Kind of Leader}

At the same time, Paul's leadership over the years at BSI involved gradually distancing himself from leadership status and the role of "Department Head", while he contested the hierarchical chain of command and strict managerial procedures of the bank. Interviewees frequently commented on Paul's unusual daily habits. In the bank's newsletter, Paul himself drew attention to his habit of cycling to work (instead of using a company car) and his "passion for philosophy and ethics" that defined his particular "style". Wearing "casual" clothes (Ludo), walking around the office barefoot or in socks (Rachel) were other examples mentioned as clear indications of his leadership "philosophy” (Tom):

"Already, [Paul] is arriving by bicycle; that in itself is alternative. That's the most visible sign to each of us. Moreover he no longer comes to meetings, everyone knows that. And everyone knows very well that that it's because of his management style, that he wants to allow everyone to take up their own responsibilities" (Nils)

Stressing the signifying value of Paul's "alternative behavior" ("the most visible sign"), Nils links these breaches of traditional etiquette to Paul's "management style", characterized by a refusal to embrace representations of symbolic authority within the bank. 
Indeed, beyond these ostensible departures from the typical banker image, Paul introduced practical changes challenging the symbolic order of the organization. Paul refused to "talk numbers" or to use the organizationally assigned objectives, marking his distance from the symbolic authority position. He publicly (within the department, at team meetings, and yearly events) took stands against the primacy of rank in strategic meetings. In a public speech on "liberation and utopian management" (2011), he cites the key elements of his approach as follows: "Give up controls - No follow up - Progressively letting go - No HR: lack of formal structure", and, finally, links the abandonment of controls with his own absence: "Disappearing: not showing up at meetings".

\section{Contesting the Bureaucratic Norms}

In line with these principles, Paul also criticized excessive reporting: "nowadays, my [management] team will fill out [the mandatory reports], but me, I do not even look at them anymore!" This quote illustrates the ambivalence of his absence of reporting. Giving responsibility to his team while offloading work onto their shoulders, Paul conferred on the six middle managers of BSI the authority to continue a symbolic documentation evacuated of value by his own refusal. Moreover, Paul stepped back from key decision-making bodies - such as weekly credit committees considering major loans - letting his subordinates replace him, having a sales agent present her client, frequently arriving late to meetings and admitting his ignorance of "technical" subjects.

"One major difference is the credit committees. [There] decision-makers have a 'life or death right' over the loans, and sales reps who know and have worked with clients, but typically don't speak...Basically, these are top executive committees, and it's the department head's turf. But here [in BSI] the sales rep goes, presents his case, argues it. The team leader, and Paul, could be there ... but we get to speak up." (Tom)

Followers such as Tom recognized the empowering effects of Paul's approach, touting opportunities to showcase their own banking and commercial expertise: "For all the case arguments, decision-making we are always consulted" (Judith). 
Nevertheless, some followers ironically note a degree of illusion in Paul's desire for absence, which is conspicuous precisely because of the expectation to lead: "Paul hasn't yet managed to make himself as useless... as he would like to believe”, says Claude. The substitution by subordinates that is supposed to be liberating is also received with ambivalence, as Ludo notes:

"I'd say what we get the most has to do with Paul's absences. There a more than a few forums where people hint to his absences, "Oh you're replacing Paul today again, how come?" this type of thing...not always nice." (Ludo)

Paul's absence posed difficulties for departmental activities, given that his signature remained mandatory for high-stake decisions even though his deputies often replaced him at meetings. In such cases, ambiguity arose as to who had the authority to conclude deals and implement decisions, with confusion in the hierarchical process and chain of command.

"I don't have the powers, the ability to make the call, to sign it, and that's also [the fact] that we are in a bank so the 'head of' [department] should make the decision and I can't contact whoever...Those for me are small things I can live with, but just a little too much freedom from Paul, just a little too much absence." (Alison)

Paul's approach, which he explicitly described as being a "liberating leader", involved a persistent emphasis on the self-recognition of his own lack of expertise. This aspect was later translated into an imaginary representation of this lack as "absence", which - as we see below - fed a potentially manipulative fantasy. The "liberating leader" gradually adopts a posture of absence, unsettling the symbolic order, which is predicated on presence.

Besides, a primary violence underlies the renewal of the collective in the initial reorganization. While the exercise of such violence is authorized by the symbolic order of the organization, the leader then openly attacks this order, detaching himself from exercising authority as an "imaginary representative" of the symbolic order. This detachment enables employees to rearrange their relation to the "rules" and "procedures" by, for instance, valuing the local, relational expertise of client needs. Yet such liberty is limited because there is no durable reconfiguration or discussion of organizational demands, which remain tightly bounded to bottom-line objectives. In short, Paul's approach constitutes a limited and perhaps instrumental attack on the symbolic order. 


\section{Overflowing Imaginary Dynamics of Identification}

A "New" Collective: Visibility and Harmony

Paul's reframing of the role of leader in BSI involved distancing himself from the day-to-day of work and from embodying symbolic authority. This transformation also involved reinforced investments at the level of images, rather than at the symbolic level, a shift with multiple implications. At the collective level, we focus on the visibility of the transformation into an innovative and competitive unit, and on the imaginary promise of harmony, among the newly purified collective.

Followers systematically referred to changes in the "culture" and the atmosphere of the team insofar as they are "perceived from outside", therefore made visible to the leader but also to the gaze of peers, functioning as a flattering mirror. Reinforcing this, Paul often claimed that the collective was now made up of "equals", reflecting each other. At a team "off-site" event in 2010, Paul described the department metaphorically as a single body: "taking the pulse of team". Visibility, linked to the leader's gaze, was central to the transformation of the department's image: "I think that the fact that we have such a visibility within the bank, that's thanks to Paul" (Alison).

Emphasizing this collective image nurtures a wish to belong and to identify with this new collective, now purified and reshaped after the leader's early purges. These imaginary investments grounded a (false) sense of unity, stability and group harmony, evidenced in the metaphors used around the new atmosphere: "Now we feel like we are one and the same unit. Yes, we are more like brothers and sisters. Before, each of us was on her island, but we were not like a full group" (Chantal). Chantal, an assistant with long experience within BSI, speaks of a "full group", and we note the repetition of the pronoun "we" (e.g. "we feel like"). Such a "feel[ing]" of wholeness, of sameness (see the family metaphor of "brothers and sisters") may suppress individual difference ("islands"), jeopardizing the singular, desiring subject in the fantasized "full group". Likewise, Nils - 
who joined the department as an intern in 2008 and later became a team manager - expresses his attachment to a cohesive collective:

"And so the priority will be that everything be harmonized, within the team. The team being BSI; and so that everybody be on the same level of 'equality', so to speak. That everybody has the same understanding." (Nils)

Nils' language evokes the attachment to a kind of fusion between "equal[s]", insisting on the homogeneity of the group, repeating "same" twice, and on the "priority...that everything be harmonized". Here, references to "equality" convey the experience of weakened symbolic authority, which otherwise would break up the imaginary symbiosis between followers/peers.

The consequences of adhesion to this ideal of a "harmonized" team may also be interpreted in terms of control. Nils speaks of the aim "that everybody has the same understanding" of work expectations. Autonomy is thus granted on the basis of this reduced, marginal, space of subjective interpretation. The words of the leader also capture well this apparent paradox: "It is a rather intense team feeling where everyone is doing her thing" (Paul).

In sum, Paul's leadership produced an overflow of imaginary dynamics at the level of the collective. These include attachments to increased "visibility", as recognition of one's existence and worth in the gaze of "equal" others. Strengthened imaginary investments among the group reflect ideal images of a harmonious, purified group, paradoxically understood as based on member autonomy, in a way that is likely to have implications for subjective and normative control.

\section{The Promise of Self-Mastery}

At the individual level, Paul expressed an emphasis on his followers' personal development and self-growth, claiming in his 2010 off-site speech that a priority "to develop your creativity and proactivity [was] more recognition and encouragement in your personal development". This emphasis involved a fantasy of self-mastery, or the autonomy to shape one's own path at work. The leader's withdrawal (from his expected presence in the "day-to-day business") translates into calls 
for individuals to "develop themselves" beyond mundane departmental tasks, especially by participating in side projects favouring the "visibility" of the followers, i.e. offering narcissistic gratifications:

"[With Paul stepping back] there is also a possibility given to quite a lot of people to get involved in side projects...This is done on top of...day-to-day tasks, so that's a personal investment, quite a lot of extra effort, which is definitely perceived positively outside of BSI...But I guess when one gets involved that way, one would also gain something in terms of personal fulfillment." (Ludo)

Openly rejecting the "rigid" order of the hierarchy, the absent leader defends young colleagues' opportunities to "develop themselves", appealing to ego and imaginary identifications evident in the above quote. Being "perceived positively" results from "extra effort" and "investment", but this is also linked to a gain in "personal fulfillment". The imaginary dimension here is evoked in the notion of "fulfillment" as an enterprising, autonomous individual.

One event in June 2011, described by three different members of BSI, illustrates this focus. Kate, a relationship manager, was invited to replace Paul at an important meeting with a big client, an idea that Alison, her direct manager at the time, supported:

"So I told her 'Listen, you will go [instead of Paul]...'. And I heard [from her]: 'Yes, but I think it's rather...not my place to...', and I said: 'Take this as a possibility to put yourself in the limelight, to gain visibility, advance your career.' She had a bilateral [interview] with Paul who pushed, encouraged her and today, she came to my office to tell me that it was such a great success, and how happy she was to have been there." (Alison)

Representing the management team affirmed Kate's identity in a new, more powerful "place", made possible by the voluntary withdrawal of Paul, which allowed her to "gain visibility". The narcissism of the imaginary ego is evident in having been chosen ("she had to be here") to "put [her]self in the limelight". Kate is invited to "take advantage" of the weakening symbolic order, with focus on selfdevelopment, putting the individual in the limelight, offering an escape from recognizing her existential lack (“not my place”). 
Nevertheless, as the leader absents himself, there is no stable reconfiguration of symbolic authority. Contrasting with Kate's experience, some employees were unsettled by the lack of anchoring points such as roles or clearly distributed functions:

"The hardest for me is that sometimes Paul would assign a task to my colleague, or he would assign it to me, or to a third person and you would never know which one was doing it, and...given Paul's way of doing, where he gives a lot of freedom...I don't know what he expected from me and I still don't! (sic)" (Michel)

In this excerpt, Michel conveys the sense of disarray that he experiences, despite his many years of experience within the bank, when faced with ever-changing assignments coupled with the "freedom" to self-manage. Within such a weakened (organizational) symbolic frame, there are few remaining established places to anchor symbolic identifications.

In short, as the "liberating leader" withdraws, weakening the symbolic structure in the department, followers are left to their own (imaginary) devices. They respond to their wish for selffulfilment at the imaginary level by over-investing in the ideal of harmony and autonomy.

\section{Nurturing a Culture of Enjoyment}

\section{Exalted Workplace}

We have seen that members of BSI emphasized being in a "happy place" (Michel). This fun and happy atmosphere was actively encouraged, resulting in the expectation that employees should be seeing these work events as enjoyable, above all. Paul and his management team frequently organized "off-site" meetings and "team building events" (soccer games, cooking classes, treasure hunts), in striking contrast to the bank's rather stern culture:

"In the afternoon we played, team-building kind of games and with other [teams] you can get to know [them], know how they react... their character...At a game or a soccer play, you don't know how people are gonna react, you can see some really have a winning mindset and others who could give a damn...I think that's good for the general mood." (Chantal)

As Chantal stresses, these opportunities to lift "the general mood" are interwoven with instrumental opportunities, including the display of a person's traits, "character", as if the game itself was an 
occasion to demonstrate an extra investment and one's identification/alignment with the 'team' spirit: "a winning mindset".

Such interweaving was a common aspect of team building events. Nils affirms his proximity to Paul's views, illustrating how workers' enjoyment can be mobilized:

"We seek really hard to foster strong, deep bonds within a team so they really fight...Last year there were some tensions...immediately, we took the team to a teambuilding...everyone took their evening off, and we went to a cooking [class] together, it was great and the next day we were back on, basically." (Nils)

Nils refers to a team building event, an after-hours fun moment. Organizing this activity channelled the enjoyment of followers into creating an exceptional ("great") moment in which pre-existing "tensions" were circumvented. Little was said about the subjective feelings underlying such “tensions".

Such examples show how "liberating" leadership captures a surplus of enjoyment among followers: the performance of the department becomes likened to how workers enjoy themselves. Paul's leadership encouraged the intensification of "positive" emotions within the group, as the register of fun and free commitment replaced constraints and duties. Similarly, management was instructed to "congratulate" employees on professional but also private "milestones", and on the “condition [to] KEEP IT SINCERE” (Paul's memo to managers, 2010).

As BSI evolved towards a regime of exacerbated enjoyment, what happened to followers who experienced disarray or difficulties in their work? For some followers, the "liberation" of enjoyment was a source of suffering, creating feelings of inadequacy, as employees realized that they could not deliver as autonomous, entrepreneurial workers. As Judith, a sales rep in the Health and Education (hereafter "Sanedu") team, explained:

"Now, it is true that the new [leadership] is demanding, and so there may be people who haven't...yes, that's right, that's another aspect, that some haven't been able to withstand it [tenir le coup] ... who didn't do anything wrong, but who...do couldn't withstand the pressure... a kind of burn out, almost." (Judith) 
Even as Judith minimizes the psychic effects ("not...able to withstand"), she recognizes their seriousness ("a kind of...burn out"). The colleague to whom she referred (a former team leader) did in fact go on sick leave, and never resumed work at BSI. This kind of breakdown illustrates two sides of the "anything is possible" mentality. On the one hand, the quote reflects the threat of failure and inadequacy of not being able to meet expectations. Yet pressure is exerted as the injunction to enjoy work, a superegoic exigency reflecting the weakness of symbolic authority in the absent leader regime. This demand exhorts employees to enjoy their conditions by withdrawing and adopting a self-effacing position, but incites deep confusion for followers:

"We have to be natural at all times and in the end, being natural is tiresome. We cannot be acting or anything, not ever, otherwise immediately something is going to break in the dynamic." (Claude)

Confronted with the difficulty of sustaining the expected happy and transparent self, Claude evokes how the injunction to enjoy creates the anxiety of "break[ing] the dynamic" and not living up to the ideal of a happy working subject.

\section{Violence and Exclusion}

The anxiety described above, finally, was felt as a kind of violence among followers. One target of violence was Frank, a newly appointed leader for the Sanedu team. Frank's entry marked the end of a period of six months of "quasi-total freedom" for the team, after the burnout of their former team leader. Joining BSI, he explained how he had faced (tacit) scrutiny from Paul, his peers, and subordinates:

"I recollect that was very important for [Paul] to assess... 'Will your personality and your approach fit well with the present team?'...I did a tour [to meet] everyone. After that, the feedback I got was, okay, there is still 'room for improvement' (smiles)...So yes, I have adapted and I have... if you are coming in with the mindset, the hard disk, of twenty years in the bank... how do I perform in this kind of environment?" (Frank)

Frank struggled to respond to the enjoyment imperative, speaking of the exigency to "adapt" to the point of transforming oneself, to show one's acculturation (to "fit well with the team") and even to 
change his "mindset...hard disk". Yet, his efforts seem never to be enough to satisfy both the leader and the peers who openly and tacitly "assess" his progression ("still room for improvement").

Team members indeed resisted his attempts to reintroduce boundaries, "rules" and "formalization". Many respondents referred to Frank's communication style as "too directive" (formal, citing organizational guidelines), and complained of his attempts to implement official controls of sales reps "performance":

"For six months we were without a boss, and now we have a new one, which isn't particularly better...it's more a general atmosphere, a changing atmosphere [...] and more reports to turn in, more feed-back to give, more obligations and constraints because doing this can sometimes be a constraint... A simple example: since 2011 we have been given a quantified objective for [the number of client] visits that we do with our boss. That wasn't here before...." (Alain)

Having experienced many months with no "obligations", Alain and his colleagues quickly rejected Frank's suggestions as "constraints" (repeated twice). The lack of such limits in their work had become invested with their own aspirations of self-development, and led them to believe in the promise of an all-enjoyment environment under Paul's absent leadership.

As the team faced lower performance (perhaps related to the financial crisis at the time) and affective discomfort (cf. Alain's quote above), the collective polarized against Frank. Alain was repeatedly singled out in interviews and characterized as an outsider. Managers from other teams took note of his difficulties but remained rather distant:

"Someone arrives from outside, understands the way to do things but isn't able to enforce it correctly, then I think there is a danger. Because then...I think the team may see it as weakness. Because sadly the "weak" ones, especially in a commercial team, they are bitten at the throat." (Nils)

Even though Nils recognizes the possible violence, as evident from his evocative metaphors ("bitten at the throat", metaphor of a wolf pack), Nils' use of the third person and general pronouns ("someone...the team...they") distances him from these conclusions, treating the mounting tensions as an internal problem that the team should self-manage.

The metaphors of violence were actually reflected in a rapid collective polarization (scapegoating) against Frank that members described as a "lobbying campaign" (Alison), during 
which two or three young relationship managers routinely expressed their discontent with Frank, openly complaining to him and other colleagues, as well as to Paul.

"Quickly we reached a limit, and trust wasn't here. And so working everyday with this manager got more and more difficult because Paul was still giving us directly all the information and we could form our opinion, he [Frank] would do too, and most likely opinions would clash. So we had to expose the clash. [...] We had to say [...] that we could not go on." (Claude)

A process of scapegoating is favoured here by the leader's (Paul) refusal to bear the symbolic law and to enforce prohibitions. The promise of permissiveness and full enjoyment incites rejection of members not invested in the fantasy, such as Frank, the poorly integrated "outsider" who cannot seem to adjust his "hard disk". The scapegoating of Frank seems to sustain the promise of enjoyment established though weakening symbolic authority.

Moreover, the relationship managers' opposition campaign met little resistance within the team, suggesting that the rest of the collective had mostly endorsed the promise of a return to the presymbolic enjoyment heralded by the liberating style:

"Personally I didn't have issues, but I think some in the team did have some... Perhaps you heard of it, there have been some...issues... some raised voices in the open space, [...] some who didn't like this style. (Judith)

Therefore, the pushing for Frank's exclusion in this "internal lobbying" campaign led to an increasing subjective isolation and exclusion, scapegoating and, ultimately, Frank's breakdown during a morning team meeting at BSI, after which he was hospitalized and subsequently transferred to another (non-managerial) position in the bank. Paul - absent on the day of Frank's breakdown left his position as Head of BSI at the end of March, going on to "transform" yet another organization, this time in the public sector.

\section{Discussion}

The case of BSI illustrates the ambivalence of post-heroic leadership. While acknowledging that many workers appreciated the new "liberating" style, they also demonstrated subjective 
suffering and interpersonal scapegoating that seemed - through a psychodynamic lens symptomatic of a deterioration of the symbolic order. We theorize this unfolding as a dynamic of weakened symbolic authority and a re-focusing on the imaginary, as depicted in Figure 1.

Insert Figure 1 about here

As Figure 1 illustrates, the absence of the leader in the liberating approach was expressed through a disdain for "bureaucracy", a lack of directives and physical presence, and an emphasis on group affective cohesion and self-mastery. Combined, these elements were emblematic of a weakened symbolic order within the organization and reinforced the fantasy of a total collective unity and a self-expressive subject. These two aspects were self-reinforcing, as the fantasy subject imagines this impossible totality as the symbolic prohibition is lifted and, in turn, the expectation of enjoyment itself delegitimizes the symbolic order. The resulting superegoic resurgence gives rise to the culture of enjoyment that we identify.

The consequence of this changing of registers from the symbolic to the imaginary is that it created a promise of enjoyment, with its correlate demand to live up to being the ideal happy worker. This demand, projected onto others as a blockage of enjoyment, is reflected in scapegoating and exclusion of those who are seen as embodying the symbolic order. Elaborating on the lessons learned below, we draw out implications for theorizing these leadership dynamics.

\section{Contributions to Post-Heroic Leadership}

The current study - at the interface of critical leadership and psychodynamic approaches builds on emerging discussions around the ambivalence of "post-heroic" leadership, demonstrating how initiatives to liberate employees can have unexpected implications for worker experience, subjectivity and interpersonal dynamics. Through our empirical exploration of post-heroic leadership, we add empirical grounding and conceptual diversity to psychodynamic approaches to 
critical leadership (Costas \& Taheri, 2012; Driver, 2013; Gabriel, 1997; Kelly, 2014; Vince \& Mazen, 2014).

Studies of post-heroic leadership (Costas and Taheri, 2012; Grint, 2010) have critiqued the pretense of contemporary leadership discourses claiming to overcome traditional notions of authority while recreating new kinds of leadership fantasies. Such discourses resonate more generally with critiques of contemporary workplaces as having façades of engagement, meaning or fun, but masking new forms of subjective control (Endrissat, Islam \& Noppeney, 2015; Fleming \& Sturdy, 2011). Collinson (2012), in his concept of "Prozac leadership", suggests that this focus on enjoyment may have a dark side, and others have linked this dark side to the complex dynamics of desire and fantasy that inhere between leaders and followers (Costas \& Taheri, 2012).

Critiques of post-heroic leadership, largely conceptual in nature, establish the need for empirical research on the ambivalent aspects of post-heroic leadership in practice. Our empirical examination of BSI shows how followers were placed in an ambivalent position vis-à-vis their leader. On the one hand, they reported a newfound freedom and appreciated the informal and collegial culture, distanced from the iron cage of the bureaucratic order. Yet, unidentified sources of social pressure and stress haunted the followers of "liberating leadership", and we were surprised by descriptions of disarray and subjective breakdown. Followers appeared at a loss when faced with the floating roles and expectations of an increasingly absent leader and weakened organizational order (Owens, 2010). Following Costas and Taheri (2012), we see in this ambivalence symptoms of the deterioration of the symbolic order. The absent, authoritative leader is replaced by a permissive superegoic figure (Verhaeghe, 2000; Vidaillet \& Gamot, 2015; Žižek, 2000), especially so in the calls to find one's "authenticity" via self-development, and to become a "happy", highly invested workforce. Absent symbolic identifications are compensated for by narcissistic fantasies of selfmastery, total collectivity, and unlimited freedom. When these fantasies - now shouldered by 
individuals - failed to materialize, the employees either blamed themselves or projected their dissatisfaction onto the image of the scapegoated outsider.

Symbolic deterioration and the fantasy of empowered followership

Central to our analysis is the mutually reinforcing nature of the imaginary fantasy and the deterioration of the symbolic. Post-heroic leaders may operate by denouncing traditional or formal leadership, or by playing on narcissistic fantasies of self-realization or unity. Not on their face related, these two dynamics shift the priority from the symbolic to the imaginary and can thus be mutually reinforcing. The consequences of adhesion to the imaginary ideal of team harmony echo earlier commentaries on the power effects of the imaginary (Roberts, 2005).

What is at stake in weakening the symbolic order of the organization, and in the surge of imaginary dynamics? In shifting towards personalized, compassionate and "empowering" leaderfollower relations, followers are "recogniz[ed] as a fellow subject" (Roberts, 2005, p.636), suggesting a complete, "full” acknowledgement of the self.

Post-heroic conceptions of egalitarian leadership draw upon fantasies of completeness and fusion with the leader, who now appears as a "small other", just like me, therefore posing "the danger of double alienation: [...] once by fostering imaginary relations and a second time by making followers think they are free" (Costas \& Taheri, 2012, p.1208). In our empirical case, the consequences of this fantasy are illustrated by the emphases on harmony and personal image, and on the self-mastery experienced as both stimulating and highly stressful.

Exploring the "liberation" of enjoyment and its darker effects

In contrast to the affirmation of its "liberating" effects, our study highlights the risk that these leadership techniques also encourage an overflow of imaginary attachments, focused on sameness and harmony, thus denying difference between subjects (Faÿ, 2008). Due to its elusive and 
intersubjective nature, this may potentially foreclose the experience of lack that is otherwise a resource in leadership (Driver, 2013; Kelly, 2014). The leader, no longer representing symbolic authority, emerges as a superegoic figure, who mobilizes and commanding followers' enjoyment.

The scapegoating effects we saw in the attacks directed against Frank are symptomatic of this dynamic. The emergence of this promise/command of full enjoyment and its superegoic turn give rise to violent dynamics against oneself manifest as guilt, and against others, in scapegoating. Frank - the newcomer - became the black sheep who was "stealing" the jouissance of others, representing the obstacle to their illusory wholeness, completeness and lost paradise (Vidaillet \& Gamot, 2015). In this case, we do not see scapegoating as the only possible outcome of the broken promise of enjoyment, but as one possible outcome; the bigger point concerns the potential violence that inheres in the promise of wholeness (Žižek, 2009), and is unleashed when the related enjoyment seems prevented.

On a more speculative note, this argument may inform reflections on how "liberated" followership supports a latent violence more generally. This point speaks to contemporary subjectivity in the post-political age, dominated by "the polymorphously perverse subject following the superego injunction to enjoy" (Žižek, 2000, p.248). Far from an emancipatory alternative, we suggest that such initiatives may not be respectful of leaders' and followers' subjectivity (Ford \& Harding, 2011). Thus, our study complements existing critiques in terms of the over-emphasis on positive thinking (Collinson, 2012; Fineman, 2006) and of neo-normative control (Fleming \& Sturdy, 2011; Roberts, 2005).

\section{Post-heroic Leadership: A Research Agenda}

Building on the current findings, we can conceptualize a research agenda linking psychodynamic approaches and emerging critiques of "positive" organizational approaches. For instance, linking a problem often associated with neo-normative organizational controls (Fleming, 
2009; Fleming \& Sturdy, 2011) to the critical psychodynamics of leadership raises the question of whether "liberating" leadership differs in its ambivalences from other "positive" approaches. Is the ambivalence seen here typical of the dark side of positive organizational approaches (Salovaara \& Bathurst, 2016), or does the moving of this critical literature into leadership raise distinct theoretical possibilities?

Liberating leadership shares many features with "happy" workplaces more generally; however, we suggest that the specific nature of the leader-follower relationship as one of symbolic authority means that making it "fun" will have a particularly destabilizing effect on the symbolic order. Further empirical work, however, should examine how such "liberating" projects may have diverse effects at different sites within organizations, since our theorizing suggests that it is not likely to be the same at any given spot. In other words, whether the balm of "liberation" is what it claims to be may depend on the point at which it is applied.

Second, as we saw, the subjective reaction to the demand for enjoyment could have quite different effects and, although we were able to observe these diverse effects in our fieldwork, future work should establish the conditions under which a specific effect would occur. In particular, the narcissistic feeling of excitement, the subjective suffering deriving from the realization of its impossibility, and the resentful scapegoating of the other as an excuse for this impossibility, all are plausible reactions to "liberating" leadership, yet are all quite different in terms of their personal and social consequences.

As with Frank, reinitiating a formal system of rules unleashed a vehement campaign to frame him as a symbol of traditional authority. Under what conditions, for example, would individuals instead take the pressure on themselves as individual suffering? Similarly, under what conditions (if at all), could the symbolic order be re-established or reinforced without creating such a backlash, given the unleashing of "liberating" identity fantasies? In short, once leadership has become reduced to a collective narcissistic fantasy, is there any way to put the genie back in the bottle? 
On a final note, an important challenge in this area is recognition that there may be something fundamentally pleasing - and perhaps even liberating - about the claimed respite from traditional forms of leadership and, in studying such leadership critically, one should be careful not to throw the baby out with the bathwater. However, equally dangerous in a workplace marked by individual breakdown, large-scale layoffs, and the occasional witch-hunt, would be to take claims of liberation at face value. Where liberation lies in the perennial struggle between the bonds of authority and the subject's struggle to loosen those bonds is a question of particular relevance in contemporary workplaces.

\section{References}

Arnaud, G. (2002). The organization and the symbolic: Organizational dynamics viewed from a Lacanian perspective. Human Relations, 55(6), 691-716.

Arnaud, G. (2012). The contribution of psychoanalysis to organization studies and management: An overview. Organization Studies, 33(9), 1121-1135.

Arnaud, G., \& Vidaillet, B. (2018). Clinical and critical: The Lacanian contribution to management and organization studies. Organization, 25(1), 69-97.

Arnaud, N., Mills, C.E. \& Legrand, C. (2016). Liberation through narrativity: A case of organization reconstruction rhrough strategic storytelling, Management International, 20(2), 107-118.

Avolio, B.J., Walumbwa, F.O., \& Weber, T.J. (2009). Leadership: Current theories, research, and future directions. Annual Review of Psychology, 60, 421-449.

Baldry, C., Bain, P., Taylor, P., Hyman, J., Scholarios, D., Marks, A., Watson, A., Gilbert, K., Bunzel, D., Gall, G. (2007). The meaning of work in the new economy. London: Palgrave Macmillan.

Böhm, S., \& Batta, A. (2010). Just doing it: enjoying commodity fetishism with Lacan. Organization, 17(3), 345-361. 
Cederström, C., \& Hoedemaekers, C. (2010). Lacan and Organization. London: MayFly Books.

Chaumon, F. (2004). Lacan. La loi, le sujet, la jouissance. Paris: Editions Michalon.

Collinson, M. (2018). Leading questions: What's new about Leadership-as-Practice? Leadership, 14(3), 363-370.

Collinson, D. (2012). Prozac leadership and the limits of positive thinking. Leadership, 8(2), 87-107.

Contu, A., Driver, M., \& Jones, C. (2010). Jaues Lacan with organization studies. Organization, 17(3), 307-315.

Costas, J., \& Taheri, A. (2012). "The return of the primal father" in postmodernity? A Lacanian analysis of authentic leadership. Organization Studies, 33(9), 1195-1216.

De Cock, C., \& Böhm, S. (2007). Liberalist fantasies: Žižek and the impossibility of the open society. Organization, 14(6), 815-836.

Demailly, L. (2011). Les nouveaux managements et la question de l'autonomie professionnelle, L'information psychiatrique, 87(6), 467-474.

Denis, J.L., Langley, A., \& Sergi, V.(2012). Leadership in the Plural. Academy of Management Annals, 6(1), 211-283.

Driver, M. (2013). The lack of power or the power of lack in leadership as a discursively constructed identity. Organization Studies, 34(3), 407-422.

Eslen-Ziya, H., \& Erhart, I. (2015). Toward postheroic leadership: A case study of Gezi's collaborating multiple leaders. Leadership, 11(4), 471-488.

Endrissat, N., Islam, G., \& Noppeney, C. (2015). Enchanting work: New spirits of service work in an organic supermarket. Organization Studies, 36(11), 1555-1576.

Fauroux, M., Niewenglowski, M., Mongellaz, T., Tupin, D., Rousseau, A. \& Cohen, A. (2015). “J’ai viré mon chef"' (I fired my boss), Complément d'enquête [TV documentary], France: France Télévisions.

Faÿ, E. (2008). Derision and management. Organization, 15(6), 831-850. 
Fineman, S. (2006). On being positive: Concerns and counterpoints. Academy of Managament Review, 31(2), 270-291.

Fleming, P. (2009). Authenticity and the cultural politics of work: New forms of informal control. Oxford: Oxford University Press.

Fleming, P., \& Sturdy, A. (2011). "Being yourself" in the electronic sweatshop: New forms of normative control. Human Relations, 64(2), 177-200.

Fletcher, J. K. (2004). The paradox of postheroic leadership: An essay on gender, power, and transformational change. Leadership Quarterly, 15(5), 647-661.

Ford, J. \& Harding, N. (2015). Followers in leadership theory: fiction, fantasy and illusion. Leadership (Online First).

Ford, J., \& Harding, N. (2011). The impossibility of the "true self" of authentic leadership. Leadership, 7(4), 463-479.

Gabriel, Y. (1997). Meeting God: When organizational members come face to face with the supreme seader. Human Relations, 50(4), 315-342.

Gabriel, Y., \& Carr, A. (2002). Organizations, management and psychoanalysis: an overview. Journal of Managerial Psychology, 17(5), 348-365.

Gardner, W.L., \& Avolio, B.J. (1998). The charismatic relationship: A dramaturgical perspective. Academy of Management Review, 23(1), 32-58.

Gemmill, G., \& Oakley, J. (1992). Leadership: An alienating social myth? Human Relations, 45(2), $113-129$.

Getz, I. (2009). Liberting leadership: How the initiative-freeing radical organizational form has been successfully adopted. California Management Review, 51(4), 32-58.

Getz, I. (2011). 1960s' Lessons learned: Liberating leadership and transformational scholarship. Journal of Management Inquiry, 20(1), 8-12.

Getz, I., \& Carney, B.M. (2009). Freedom, Inc. New York City: Crown Business. 
Gilbert, P., Raulet-Crozet, N. \& Teglborg, C. (2014). Figures du client et management : un processus de structuration sous contrôle(s), Gérer \& Comprendre, 118, 67-77.

Glaser, B., \& Strauss, A. (1967). The discovery of grounded theory: Strategies for qualitative research. Chicago: Aldine.

Grint, K. (2010). The Sacred in Leadership: Separation, Sacrifice and Silence. Organization Studies, 31(1), 89-107.

Harding, N., Lee, H., Ford, J., \& Learmonth, M. (2011). Leadership and charisma: A desire that cannot speak its name? Human Relations, 64(7), 927-949.

Holtz, T. (2017). Mutations du leadership dans une entreprise en voie de libération, RIPCO, 23(2), 125-140.

Islam, G. (2014). Identities and ideals: Psychoanalytic dialogues of self and leadership. Leadership, 10(3), 344-360.

Jaumier, S. (2017). Preventing chiefs from being chiefs: An ethnography of a co-operative sheetmetal factory. Organization, 24(2), 218-239.

Johnsen, R., \& Gudmand-Høyer, M. (2010). Lacan and the lack of humanity in HRM. Organization, 17(3), 331-344.

Jones, C., \& Spicer, A. (2005). The sublime object of entrepreneurship. Organization, 12(2), 223246.

Kelly, S. (2014). Towards a negative ontology of leadership. Human Relations, 67(8), 905-922.

Kenny, K. (2012). "Someone big and important": Identification and affect in an international development organization. Organization Studies, 33(9), 1175-1193.

Kets de Vries, M. (1991). Organizations on the couch: Clinical perspectives on organizational behavior and change. San Francisco: Jossey-Bass.

Kosmala, K., \& Herrbach, O. (2006). The ambivalence of professional identity: On cynicism and jouissance in audit firms. Human Relations, 59(10), 1393-1428. 
Kotter, J.P. (1990). What leaders really do. Harvard Business Review, (May-June), 103-111.

Lacan, J. (1998). The Four Fundamental Concepts of Psychoanalysis (Seminar IX). Trans. A. Sheridan, ed. J.-A. Miller. London: Vintage.

Lacan, J. (2006). Ecrits. New York: W.W.Norton and Company.

Landivar, D. \& Trouvé, P. (2017). «Eprouver les entreprises libérées ». Revue internationale de psychosociologie et de gestion des comportements organisationnels, 23, p.47-61.

Leonard, P. (2007). The romance of collaborative leadership. In The British Academy of Management Conference. Warwick University.

Meindl, J.R., Ehrlich, S.B., \& Dukerich, J.M. (1985). The romance of leadership. Administrative Science Quarterly, 30(1), 78.

Meissonnier, M. (2014). Le Bonheur au Travail [TV]. Arte/Campagne Première.

Müller, M. (2012). Lack and jouissance in hegemonic discourse of identification with the state. Organization, 20(2), 279-298.

Owens, C. (2010). Danger! Neurotics at work. In C. Cederström \& C. Hoedemaekers (Eds.), Lacan and Organization (pp. 187-210). London: MayFly Books.

Parker, I. (2005). Lacanian discourse analysis in psychology: Seven theoretical elements. Theory \& Psychology, 15(2), 163-182.

Pearce, C.L., Conger, J.A., \& Locke, E.A. (2008). Shared leadership theory. The Leadership Quarterly, 19(5), 622-628.

Petriglieri, G., \& Stein, M. (2012). The unwanted self: Projective identification in leaders' identity work. Organization Studies, 33(9), 1217-1235.

Raelin J.A.(2016) Leadership-as-practice: Theory and application: An editor's reflection. Leadership 13(2): $215-221$

Roberts, J. (2005). The power of the "imaginary" in disciplinary processes. Organization, 12(5), $619-642$. 
Salecl, R. (1994). The spoils of freedom: Psychoanalysis and Feminism after the Fall of Socialism. London: Routledge.

Salovaara, P., \& Bathurst, R. (2016). Power-with leadership practices: An unfinished business. Leadership (Online first).

Schedlitzki, D., Edwards, G., \& Kempster, S. (2017). The absent follower: Identity construction within organisationally assigned leader-follower relations. Leadership (Online first).

Semler, R. (1993). Maverick: The Success Story Behind the World's Most Unusual Workplace. Warner Books.

Smircich, L., \& Morgan, G. (1982). Leadership: The management of meaning. The Journal of Applied Behavioral Science, 18(3), 257.

Stavrakakis, Y. (2007). The Lacanian Left. Psychoanalysis, Theory, Politics. Edinburgh University Press.

Stavrakakis, Y. (2008). Peripheral vision: Subjectivity and the organized other: Between symbolic authority and fantasmatic enjoyment. Organization Studies, 29(7), 1037-1059.

Strauss, A.L., \& Corbin, J. (1990). Basics of Qualitative Research. Grouded Theory Procedures and Techniques. London: SAGE Publications.

Sutherland, N., Land, C., \& Böhm, S. (2014). Anti-leaders(hip) in Social Movement Organizations: The case of autonomous grassroots groups. Organization, 21(6), 759-781.

Vanheule, S., Lievrouw, A., \& Verhaeghe, P. (2003). Burnout and intersubjectivity: A psychoanalytical study from a Lacanian perspective. Human Relations, 56(3), 321-338.

Verhaeghe, P. (2000). The collapse of the function of the father and its effect on gender roles. In R. Salecl, Sexuation (pp. 131-154). Durham, London: Duke University Press.

Verhezen, P. (2010). Giving voice in a culture of silence. From a culture of compliance to a culture of integrity. Journal of Business Ethics, 96(2), 187-206. 
Vidaillet, B., \& Gamot, G. (2015). Working and resisting when one's workplace is under threat of being shut down: A Lacanian perspective. Organization Studies, 36(8), 987-1011.

Vince, R., \& Mazen, A. (2014). Violent innocence: A contradiction at the heart of leadership. Organization Studies, 35(2), 189-207.

Žižek, S. (1989). The sublime object of ideology. London: Verso.

Žižek, S. (2000). The ticklish subject: The absent centre of political ontology. London: Verso.

Žižek, S. (2009). Violence: Six sideways reflections. London: Profile Books. 


\begin{tabular}{|c|c|c|}
\hline $\begin{array}{l}\text { DATA } \\
\text { SOURCE }\end{array}$ & DATA FORMAT/TYPE & USE IN THE ANALYSIS \\
\hline \multirow[t]{2}{*}{ Interviews } & $\begin{array}{l}\text { First round (Nov-Dec 2011) } 27 \text { interviews: } 15 \text { BSI } \\
\text { members (including head of department, } 7 \text { team leaders, } 7 \\
\text { relationship managers, } 1 \text { credit analyst, } 1 \text { administrative } \\
\text { assistant); and } 11 \text { from other business units in the bank ( } 6 \text { top } \\
\text { managers, } 5 \text { direct collaborators of BSI) }\end{array}$ & $\begin{array}{l}\text { Gather information regarding the changes introduced } \\
\text { by "Paul": motives, perceptions, day-to-day experience } \\
\text { Focus on affective dimensions and investigate the } \\
\text { differences, conflicts and recurrences across and within } \\
\text { interviews }\end{array}$ \\
\hline & $\begin{array}{l}\text { Second round (Dec 2012)20 interviews: } 15 \text { BSI } \\
\text { members (6 team leaders, } 6 \text { relationship managers, } 1 \text { credit } \\
\text { analyst, } 1 \text { administrative assistant); and } 5 \text { members from } \\
\text { other units ( } 2 \text { department heads, } 3 \text { direct collaborators of BSI) }\end{array}$ & $\begin{array}{l}\text { Confirm a timeline of facts } \\
\text { Assess changes in leadership after the departure of } \\
\text { "Paul": how do employees reflect on the experience of } \\
\text { "absent" leadership? }\end{array}$ \\
\hline
\end{tabular}


Ambivalent Effects of Liberating Leadership 39

\begin{tabular}{|c|c|c|}
\hline $\begin{array}{r}\text { Internal } \\
\text { archival sources }\end{array}$ & $\begin{array}{l}\text { Powerpoint presentations (internal / external) } \\
\text { Internal e-mails (team briefings, newsletter) }\end{array}$ & $\begin{array}{l}\text { Enrich interview data by tracking recurring words, } \\
\text { phrases and images, to strengthen analytical categories such as } \\
\text { "visibility" and "enjoyment" }\end{array}$ \\
\hline $\begin{array}{r}\text { External } \\
\text { archival data }\end{array}$ & $\begin{array}{l}\text { Specialized press articles and TV documentaries on } \\
\text { "liberated companies", featuring "Paul", }\end{array}$ & $\begin{array}{l}\text { Triangulate observations made from internal data and } \\
\text { interviews } \\
\text { Contextualize the meaning of the case and confirm } \\
\text { patterns of absent / distant leadership }\end{array}$ \\
\hline
\end{tabular}




\begin{tabular}{|l|l|l|}
\hline \multicolumn{1}{|c|}{ FIRST-ORDER CONCEPTS } & SECOND-ORDER THEMES & AGGREGATE \\
& CONSTRUCTS \\
\hline $\begin{array}{l}\text { - Driven by performance goals: ambivalent use of symbolic } \\
\text { position } \\
\text { - A brutal experience of exclusion/selection } \\
\text { - Purification }\end{array}$ & Shaping the followers' group & Weakening the symbolic \\
\hline $\begin{array}{l}\text { - Disturbing the daily routines and self-presentation of a top } \\
\text { manager } \\
\text { - Recognizing lack of expertise and stepping away }\end{array}$ & A different kind of leader & order through leader's absence \\
\hline $\begin{array}{l}\text { - Opposing key organizational processes (appraisal, reporting) } \\
\text { - Challenging hierarchical primacy in decision-making }\end{array}$ & norms & bureaucratic \\
\hline
\end{tabular}

- A collective of equals (sameness)

- An attractive image within the bank (collective)

- Narcissistic gratifications (individual)

- Primacy of self-growth, personal development

- Lack of clear directions: anxiety
A new collective: harmony and visibility

\section{The promise of self-mastery}

\section{Overflowing imaginary}

dynamics of identification

- Permissive culture: all is possible, free commitment

- Fun and happiness at work

- Guilt and threat of failure

- Aggressiveness against the outcast

- Refusal of rules
Nurturing a culture of enjoyment 


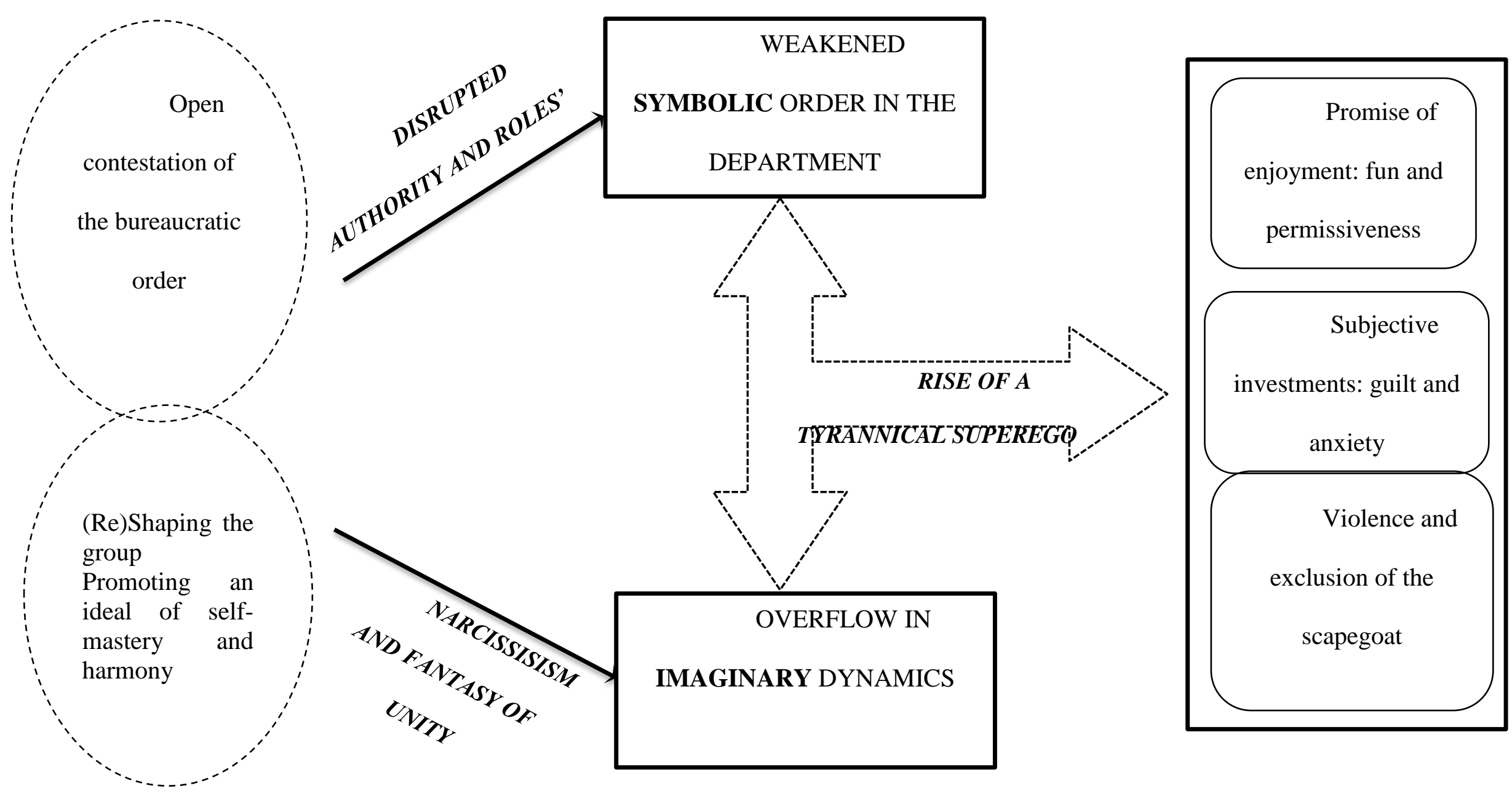


Ambivalent Effects of Liberating Leadership 42 